\title{
Nonlinear Performance Evaluation of High Rise Building Structure
}

\author{
Rifqi Fauzan ${ }^{1 *}$, Erizal ${ }^{2}$ and Asep Sapei ${ }^{3}$ \\ ${ }^{1}$ Graduate Student, Department of Civil and Environmental Engineering, Bogor Agricultural University \\ Bogor Agricultural University (IPB), PO Box 220 Bogor. 16002 (Bogor, Indonesia) \\ ${ }^{2}$ Lecture, Department of Civil and Environmental Engineering, Bogor Agricultural University \\ Bogor Agricultural University (IPB), PO Box 220 Bogor. 16002 (Bogor, Indonesia) \\ ${ }^{3}$ Professor, Department of Civil and Environmental Engineering, Bogor Agricultural University \\ Bogor Agricultural University (IPB), PO Box 220 Bogor. 16002 (Bogor, Indonesia) \\ ${ }^{*}$ Corresponding author's email: rifqi.eqi [AT] gmail.com
}

\begin{abstract}
Performance evaluation can provide information on how far an earthquake will affect building structure. This is important for evaluating the seismic behavior of post-yield building structures. The purposes of this study were to evaluate the story shear force that occurred, evaluate the distribution of plastic hinge, and evaluate the high rise building structure performance level during an earthquake. This research was conducted using static nonlinear analysis and calculated using capacity spectrum method. The plastic hinges that formed in the global-x and global-y direction are 1 and 52. Several elements are in collapse prevention level. This shows the element behavior and performance on performance point are not good. The performance level of building structure based on the calculation is damage control. The results show that the building structure is not efficient enough, because for a return period of 2500 years based on SNI 1726-2012, building performance is expected at life safety level.
\end{abstract}

Keywords - Performance, Nonlinear, Earthquake, Structure

\section{INTRODUCTION}

Earthquakes can cause destruction and take human lives by structurally damaging buildings and dwellings [1]. Indonesia is a country that located between circum-Pacific earthquake belt and trans-Asiatic earthquake belt, it causes the probability of an earthquake will occur is very high [2]. One of The measures used in order to combat or reduce the devastating effects of earthquakes is through the seismic risk assessment of existing buildings [3].

An approach analysis needed to calculate the lateral load caused by an earthquake to minimize the damage [4]. The latest design technique, performance based seismic design is a technique which utilizes computer based nonlinear analysis technique to determine the inelastic behavior of structures from various type of earthquake intensity so it is able to find the performance in critical condition [5].

Performance based design can be viewed as a multi-level design approach that additionally has explicit concern for the performance of a building at intermediate limit states related to such issues as occupancy and life safety standards [6]. In the newly developed performance-based seismic design approach, nonlinear analysis procedures become important in identifying the patterns and levels of damage for assessing a structure's inelastic behavior and for understanding the failure modes of the structure during severe seismic events [7]. In this methodology, every building is designed to have the desired levels of seismic performance corresponding to different specified levels of earthquake ground motion [8].

Linear analysis such as linear time history or response spectrum analysis can calculate earthquake loads, but cannot be used to predict building performance against large earthquake. The most commonly adopted method is non-linear static analysis, popularly known as pushover analysis [9]. This procedure can be effectively used as an evaluation method to check the acceptability of a particular structural design [10].

Pushover analysis is a static nonlinear procedure in which the magnitude of the structural loading is incrementally increased in accordance with a certain predefined pattern. With the increase in the magnitude of the loading, weak links and failure modes of the structure are identified [11]. The static pushover analysis is gaining significance as one of the popular tools for evaluating seismic performance of new and existing structures [9]. The expectation is that the pushover 
analysis will provide adequate information on seismic demands imposed by the design ground motion on the structural system and its components [12].

Performance evaluation can give information about how far an earthquake would affect building structure [13]. Performance evaluation is important to evaluate seismic behavior of post yield buildings. Therefore the purpose of this study were to evaluate the story shear force that occurred, evaluate the plastic hinge distribution, evaluate high rise building structure performance level during an earthquake.

\section{MATERIALS AND METHOD}

This research was conducted from May to December 2018. This research object was Building X. Building X is an apartment located in South Tangerang. This research was conducted using ETABS 2016, using pushover analysis accordance with ATC-40 [14]. The procedure includes gathering data collection, load calculation, making response spectrum curve, and structure modeling followed by analysis using pushover method. The research scheme is presented in Figure 1.

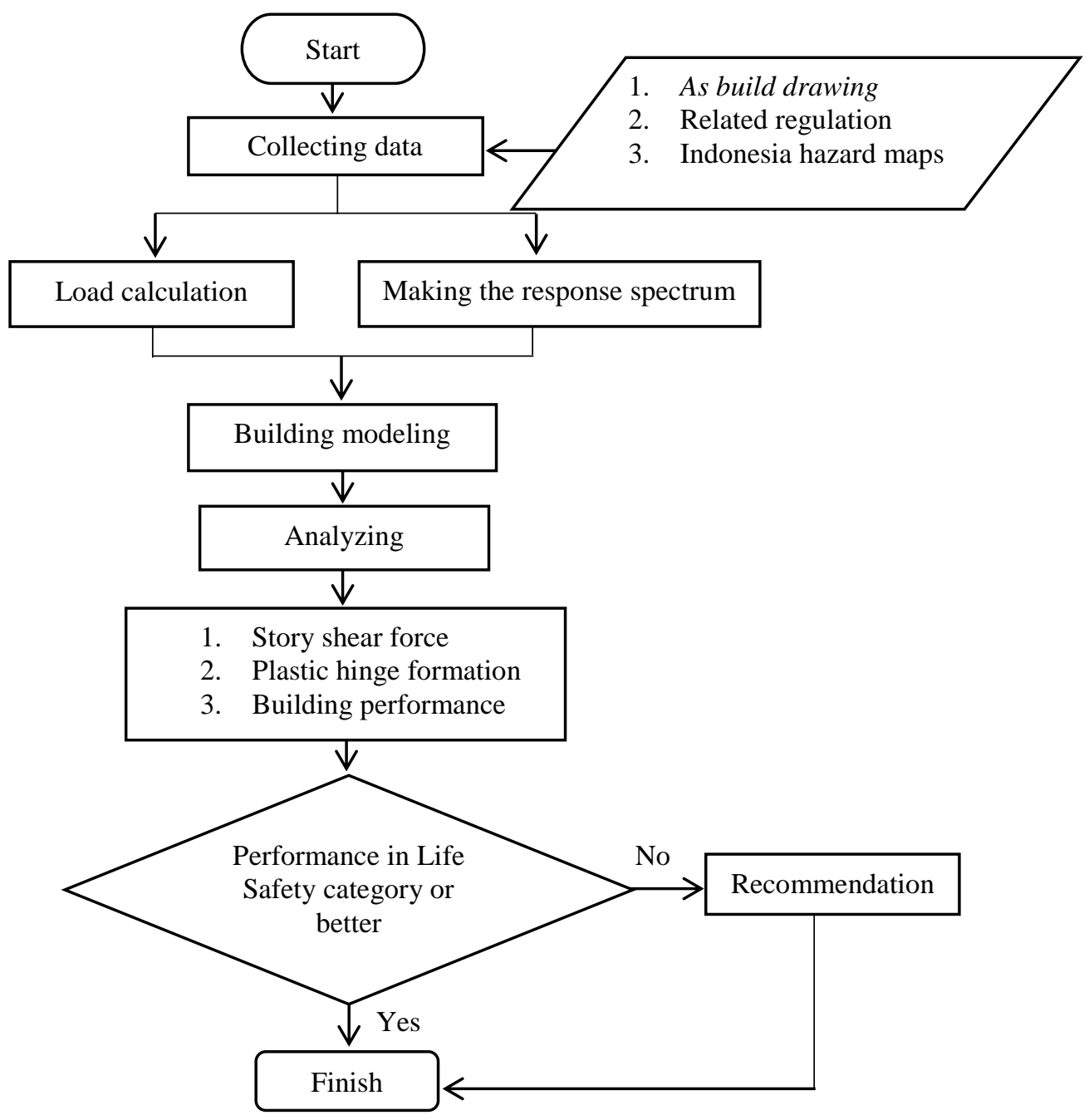

Figure 1: Flowchart of the research procedure

The load used in this analysis was dead load, superimposed dead load, live load, and lateral load. The load used in this research was based on SNI 1726-2012 [15], SNI 1727-2013 [16], and PPURG 1987 [17]. Making the response spectrum curve was accordance with SNI 1726-2012 [15]. Earthquake accelerogram as the input of ground motion was modified based on frequency zone so it fits with the response spectrum design standard acceleration. Building $\mathrm{X}$ is stand on type E soil (soft soil). Parameters used for making response spectrum curve presented in Table 1. 
Table 1 : Response spectrum design parameters

\begin{tabular}{|c|c|c|c|c|c|}
\hline Variable & Value & Variable & Value & Variable & Value \\
\hline PGA (g) & 0.375 & $\mathrm{~F}_{\mathrm{PGA}}$ & 0.974 & $\mathrm{~S}_{\mathrm{M} 1}(\mathrm{~g})$ & 0.860 \\
\hline $\mathrm{S}_{\mathrm{S}}(\mathrm{g})$ & 0.722 & $\mathrm{~F}_{\mathrm{A}}$ & 1.256 & $S_{D S}(g)$ & 0.605 \\
\hline $\mathrm{S}_{1}(\mathrm{~g})$ & 0.313 & $\mathrm{Fv}_{\mathrm{V}}$ & 2.750 & $\mathrm{~S}_{\mathrm{D} 1}(\mathrm{~g})$ & 0.573 \\
\hline $\mathrm{C}_{\mathrm{RS}}$ & 1.001 & PSA (g) & 0.366 & $\mathrm{~T}_{0}$ (second) & 0.190 \\
\hline $\mathrm{C}_{\mathrm{R} 1}$ & 0.938 & $\mathrm{~S}_{\mathrm{MS}}(\mathrm{g})$ & 0.907 & $\mathrm{~T}_{\mathrm{S}}$ (second) & 0.948 \\
\hline
\end{tabular}

AutoCAD 2016 and ETABS 2016 were used for modeling Building X. Modeling building was conducted based on as built drawing of the building. Building structure made on the model was plate, column, beam, and shear wall. Building substructure or foundation was modeled as a fixed joint. Running analysis process conducted based on SNI 1726-2002 [18], SNI 1726-2012 [15], and ATC-40 [14].

\section{RESULTS AND DISCUSSIONS}

\subsection{Load Assignment}

.Lateral load used in the analysis was based on ATC-40[14], it is a lateral load which shows the character of structure mode. Therefore, lateral load that used was story shear due to response spectrum loads while reaching $90 \%$ of mass participation. Lateral load was performed by continuing gravity load, Figure 2 shows the response spectrum curve used in the calculation and Table 2 shows the value and distribution of CQC load force as lateral load in $\mathrm{x}$ and $\mathrm{y}$-direction.

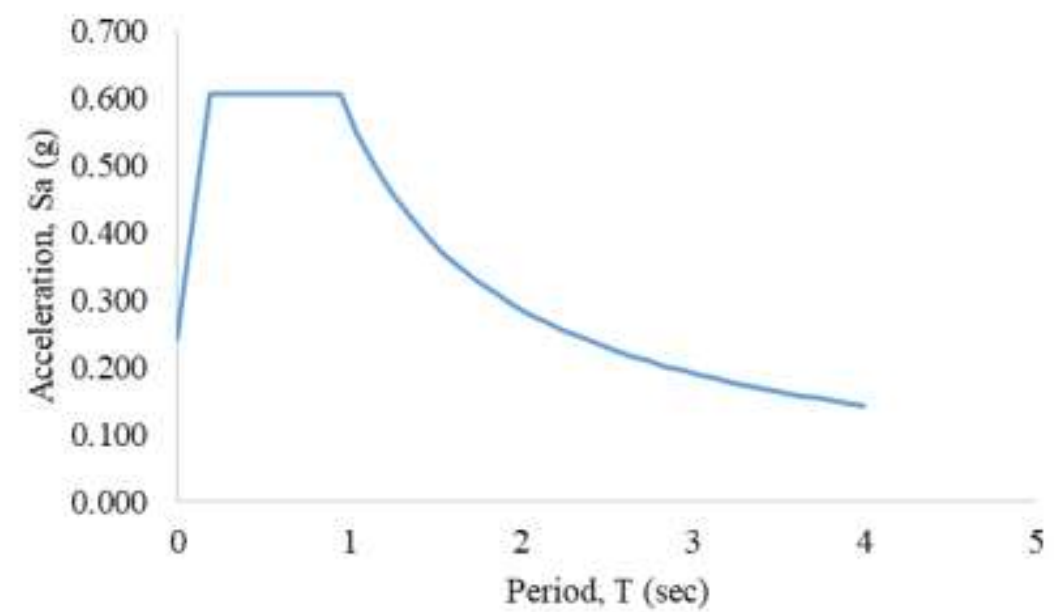

Figure 2 : Response spectrum design

Table 2 : Lateral load in $\mathrm{X}$ and $\mathrm{Y}$ direction

\begin{tabular}{cccccccrr}
\hline Story & $\begin{array}{c}\text { X-direction } \\
(\mathrm{kN})\end{array}$ & $\begin{array}{c}\text { Y-direction } \\
(\mathrm{kN})\end{array}$ & Story & $\begin{array}{c}\text { X-direction } \\
(\mathrm{kN})\end{array}$ & $\begin{array}{c}\text { Y-direction } \\
(\mathrm{kN})\end{array}$ & Story & $\begin{array}{c}\text { X-direction } \\
(\mathrm{kN})\end{array}$ & $\begin{array}{c}\text { Y-direction } \\
(\mathrm{kN})\end{array}$ \\
\hline Roof & 470.843 & 333.612 & 11 & 119.324 & 130.348 & 6 & 120.004 & 84.795 \\
15 & 351.792 & 277.249 & 10 & 101.919 & 108.144 & 5 & 120.030 & 86.907 \\
14 & 267.103 & 237.020 & 9 & 97.254 & 94.132 & 4 & 157.188 & 123.970 \\
13 & 197.472 & 196.670 & 8 & 103.801 & 86.393 & 3 & 180.241 & 174.305 \\
12 & 149.574 & 160.532 & 7 & 113.938 & 83.670 & 2 & 60.002 & 87.675 \\
\hline
\end{tabular}




\subsection{Capacity Curve}

Nonlinear static analysis (pushover analysis) was performed by using load pattern referred to ATC-40 [14]. The lateral load on the Table 2 was distributed to center of mass on each floor. The load pattern will produce capacity curve (correlation between base shear and roof displacement) which shows changing of structural behavior from linear to nonlinear in the form of stiffness transformation and plastic hinge are formed.

Based on the capacity curve, it shows a different results between global-X direction and global-Y direction. Global$\mathrm{X}$ direction result shows the condition of building structure was still elastic, while lateral load in global-Y direction indicate different result, it reveals the building structure was turn into inelastic condition. Figure 3 indicates relationship between base shear and floor displacement for each global direction.
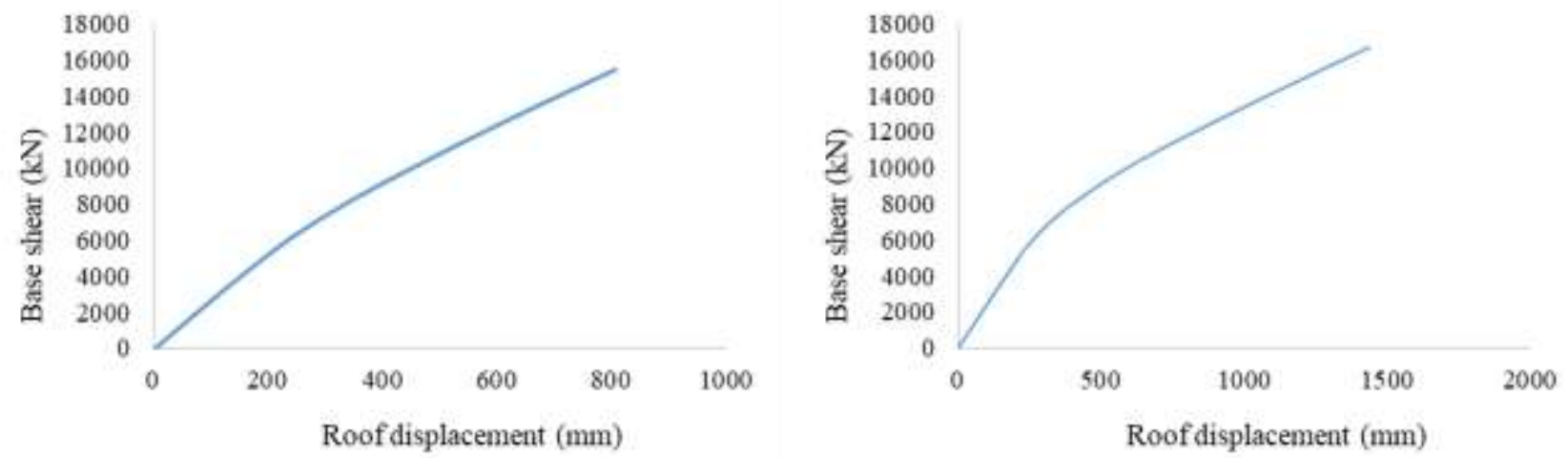

Figure 3 : Capacity curve in global-X direction (left) and global-Y direction (right)

\subsection{Story Shear Force}

Story shear is the graph showing how much lateral load, be it wind or seismic, is acting per story. Typically, the story force acting horizontally on a multi-story structure is proportionally calculated to the height of weight acting upon each story. However if dynamic load such as earthquake is acting on it, this rule does not apply to the distributed load acting upon every story under the influence of higher vibration modes [19]. Story shear force caused by lateral force in global-X direction and global-Y direction is shown in Figure 4.
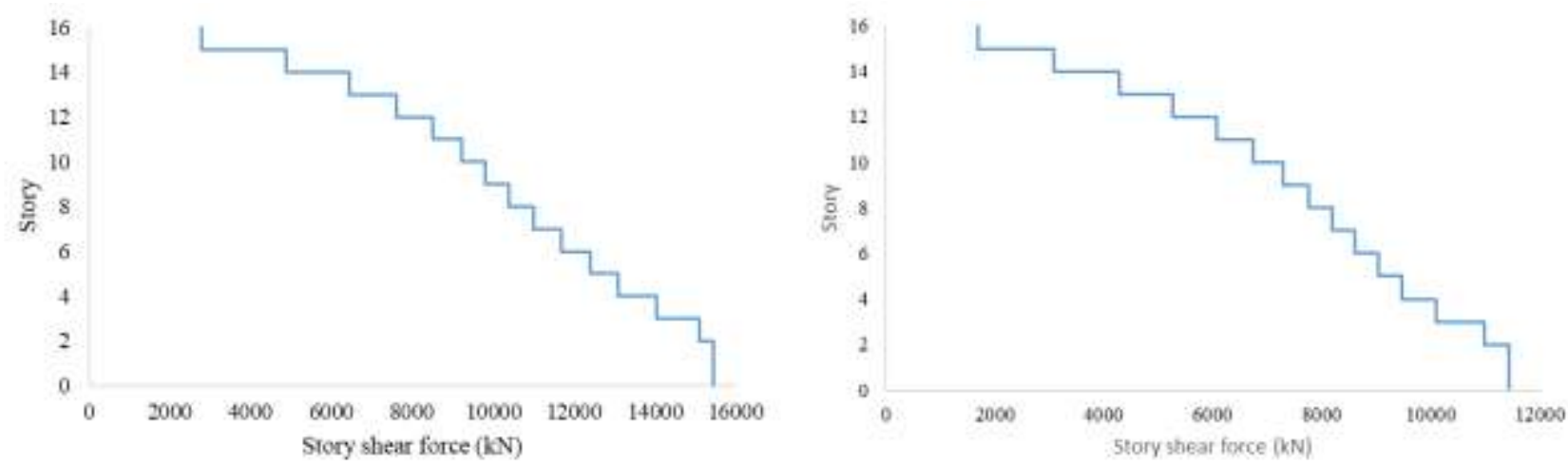

Figure 4 : Story shear force in global-X direction (left) and global-Y direction

\subsection{Plastic Hinge Distribution}

Amount of plastic hinge occurred in both global directions is shown in Table 3, while Figure 5 reveals plastic hinge distribution caused by lateral force of both directions. Figure 5 and Table 3 indicate the stiffness of structure in global-X direction is still in elastic phase, and consequently the structure performance point can only be found in global-Y direction.

Table 1 : Plastic hinge distribution

\begin{tabular}{lr}
\hline \multicolumn{1}{c}{ Direction } & Amount of plastic hinges \\
\hline Global-X & 1 \\
Global-Y & 52 \\
\hline
\end{tabular}



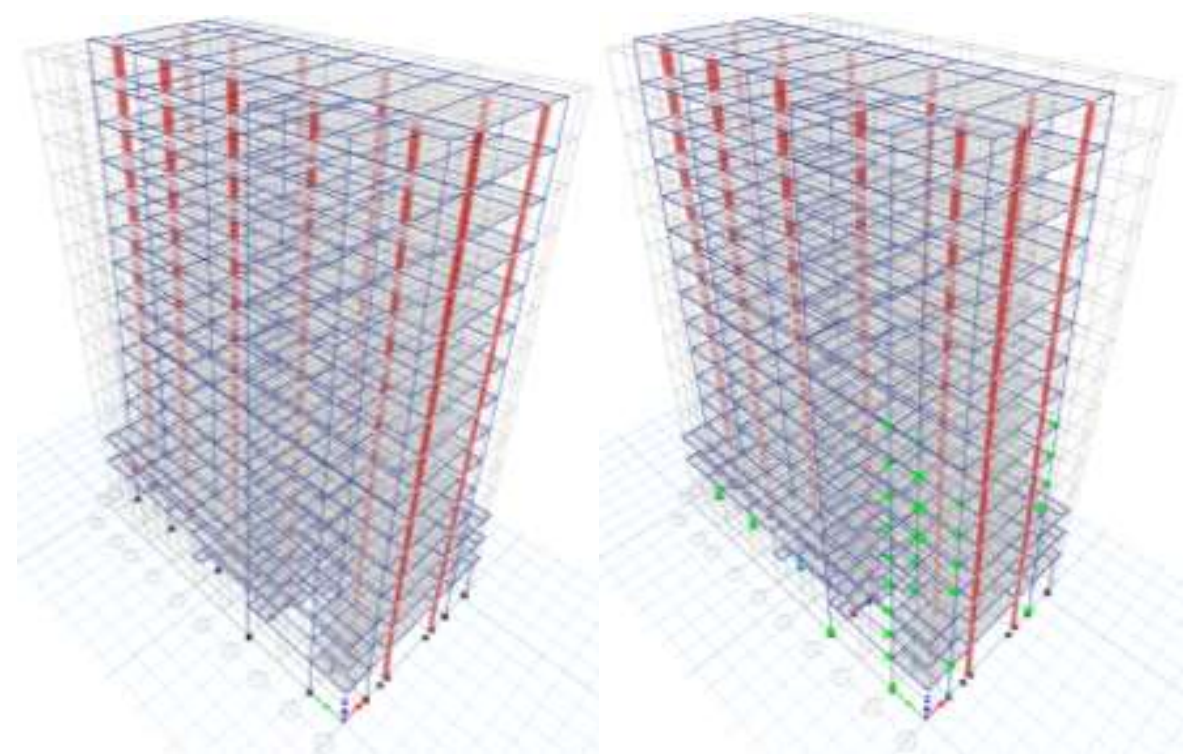

Figure 5 : Plastic hinge distribution in global-X direction (left) and global-Y direction (right)

\subsection{Performance Level}

Performance level analysis on element of the structure was conducted by checking the performance level of structural elements. Every structural element was checked to show behavior and performance of each elements on the performance point. Figure 6 shows several elements are in collapse prevention (CP) level. It indicates behavior and performance level of the structural elements are not good.

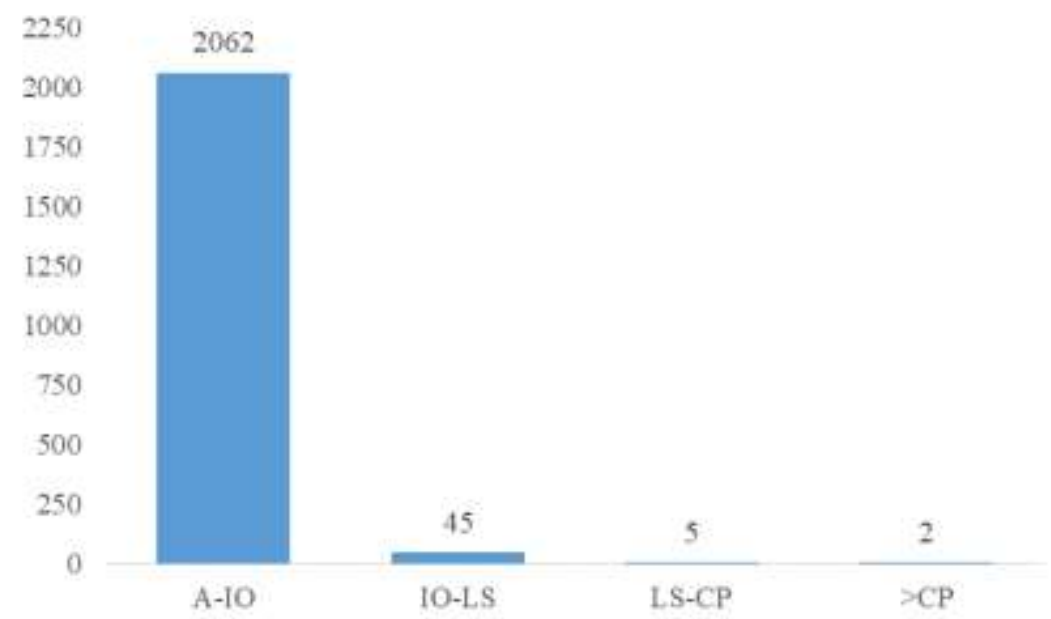

According to [20] it is necessary to determine some of important points which useful for knowing the structure behavior. Those points are maximum capacity, performance point, first yield, design capacity, and maximum elastic capacity. Base shear and displacement of those points are shown in Table 4.

Table 2 : Structural behavior observation points

\begin{tabular}{lrr}
\hline Points & $\mathrm{V}(\mathrm{kN})$ & \multicolumn{1}{c}{$\Delta(\mathrm{mm})$} \\
\hline Capacity & 16717.745 & 1441.096 \\
Performance point & 12793.337 & 926.562 \\
First yield & 6881.466 & 290.657 \\
Design & 2265.431 & 95.686 \\
Maximum elastic & 12459.870 & 526.276 \\
\hline
\end{tabular}


According to [20], design parameters such as response modification factor $(\mathrm{R})$, deflection amplification factor $\left(\mathrm{C}_{\mathrm{d}}\right)$, system overstrength factor $\left(\Omega_{\mathrm{o}}\right)$ can be evaluate using observation points. The value of $\mathrm{R}, \mathrm{C}_{\mathrm{d}}$, and $\Omega_{\mathrm{o}}$ used on the building were 5.5, 4.5, and 2.5. Evaluation was done using equal displacement method from FEMA 451B and using performance point.

The equal displacement method evaluation assumes the ductility required by plastic-designed structures is at the point where displacement of elastic structure $(R=1)$ is equal with displacement of plastic structure. According to the assumption the value of $\mathrm{R}, \mathrm{C}_{\mathrm{d}}$, and $\Omega_{\mathrm{o}}$ can be evaluate.

$$
\begin{gathered}
R_{\text {actual }}=\frac{V_{e}}{V_{y}}=\frac{12459.870}{6881.466}=1.811<R_{\text {design }}(O K) \\
C_{d}=\frac{\Delta_{e}}{\Delta_{y}}=\frac{526.276}{290.657}=1.811<C_{d \text { design }}(O K) \\
\Omega_{0}=\frac{V_{\text {capacity }}}{V_{y}}=\frac{16717.745}{6881.466}=2.429<\Omega_{0 \text { design }}(O K)
\end{gathered}
$$

Performance point evaluation means using performance point as a guidance for design parameter evaluation. $\mathrm{R}$ value cannot be determined, but can be evaluate whether it meets the requirement or not.

$$
\begin{gathered}
\frac{V_{y}}{V_{d}}=\frac{6881.466}{2265.431}=3.038>1(R \text { value } \rightarrow O K) \\
C_{d}=\frac{\Delta_{p p}}{\Delta_{y}}=\frac{926.562}{290.657}=3.188<C_{d \text { design }}(O K) \\
\Omega_{0}=\frac{V_{p p}}{V_{y}}=\frac{12793.337}{6881.466}=1.859<\Omega_{0 \text { design }}(O K)
\end{gathered}
$$

Based on ATC-40 [14], performance level of the structure can be measured from the ratio of maximum roof displacement with total height of the structure. The ratio obtained is compared with the deformation limits on Table 5. According to the ratio, building structure performance level is damage control. In accordance to SNI 1726-2002 [18] for return period of 500 years, generally building performance is expected in life safety condition. The result shows the building structure is not efficient enough, because for a return period of 2500 years based on SNI 1726-2012 [15], building performance is at damage control level.

$$
\text { rasio }=\frac{\Delta_{p p}}{h_{\text {total }}}=\frac{926.562}{49700}=0.018
$$

Table 5 : Deformation limits (ATC-40)

\begin{tabular}{lrrrr}
\hline & \multicolumn{4}{c}{ Performance Level } \\
\cline { 2 - 5 } \multicolumn{1}{c}{ Interstory Dirft Limit } & $\begin{array}{l}\text { Immediate } \\
\text { Occupancy }\end{array}$ & $\begin{array}{l}\text { Demage } \\
\text { Control }\end{array}$ & $\begin{array}{l}\text { Life } \\
\text { Safety }\end{array}$ & $\begin{array}{l}\text { Structural } \\
\text { Stability }\end{array}$ \\
\hline Maximum Total Drift & 0.01 & $0.01-0.02$ & 0.02 & $0.33 \mathrm{Vi} / \mathrm{Pi}$ \\
Maximum Inelastic Drift & 0.005 & $0.005-0.015$ & no limit & no limit \\
\hline
\end{tabular}




\section{CONCLUSION}

The conclusion can be drawn from the research are as follows:

1. According to the lateral force distributed on each floor, the story shear force the global-X direction and global-Y direction have been obtained. There are a different result between story shear force in each direction, it shows the story shear force occurred in global-X direction is on every floor are bigger than story shear force occurred in globalY direction.

2. There are more plastic hinges occurred in global-Y direction than in global-X direction. It indicate the stiffness of structure in global-X direction is still in elastic phase. The plastic hinges that formed in the global-X direction and global-Y direction are 1 and 52.

3. The building structure performance level is damage control. It shows the building structure is not efficient enough, because for a return period of 2500 years based on SNI 1726-2012 [15], building performance is expected at life safety level.

\section{ACKNOWLEDGEMENT}

Authors would like to expresses appreciation to Muhammad Fauzan, S.T., and Hamzah Arief S.T., who helped us during the process of this research.

\section{REFERENCES}

[1] Dong P, Guo H, "A Framework for automated assessment of post-earthquake building damage using geospatial data", International Journal of Remote Sensing, vol. 33, no. 1, pp.81-100, 2012.

[2] Mamesah H Y, "Analisis Pushover pada Bangunan dengan Soft First Story", International Journal of Remote Sensing, vol. 33, no. 1, pp.81-100, 2012.

[3] Dya A F C, Oretaa A W C, "Seismic Vulnerability Assessment of Soft Story Irregular Buildings using Pushover Analysis", Proceeding of The 5th International Conference of Euro Asia Civil Engineering Forum (EACEF-5), pp. 925-932, 2012.

[4] Nurhadi M, Budi A S, Supardi, "Evaluasi Kinerja Gaya Gempa pada Struktur Gedung Bertingkat dengan Analisis Pushover berdasar pada Drift dan Displacement menggunakan Software Etabs (Studi Kasus : Hotel di Wilayah Karanganyar)", e-Jurnal Matriks Teknik Sipil, vol. 2, no. 2, pp.123-130, 2014.

[5] Dewobroto W, "Evaluasi Kinerja Bangunan Baja Taha Gempa dengan SAP2000", Computers and Structurs, vol. 8, no. 3, pp.2483-2943, 2002.

[6] Hasan R, Xu L, Grierson D E, "Push-over Analysis for Performance Based Seismic Design”, Jurnal Teknik Sipil, vol. 3, no. 1, pp.7-24, 2006.

[7] Zou X K, Cham C M, "Optimal Seismic Performance-Based Design of Reinforced Concrete Buildings using Nonlinear Pushover Analysis", Engineering Structure, vol. 27, no. 8, pp.1289-1302, 2005.

[8] Tso W K, Moghadam A S, "Pushover Procedure for Seismic Analysis of Buildings", Progress in Structural Engineering and Materials, vol. 1, no. 3, pp.337-344, 1998.

[9] Kovela P R, Balaji K V G D, Raju G S S S V, Rao S S, "Nonlinear Pushover Analysis for Performance Based Engineering Design - A Review”, International Journal for Research in Applied Science \& Engineering Technology, vol. 5, no. 3, pp.1293-1300, 2017.

[10] Mahdi T, Gharraie S, "Plan Irregular RC Frames: Comparison of Pushover with Nonlinear Dynamic Analysis", Asian Journal of Civil Engineering (Building and Housing), vol. 12, no. 6, pp.213-224, 2011.

[11] Khan R A, "Performance Based Seismic Design of Reinforced Concrete Building", International Journal of Innovative Research in Science, Engineering and Technology, vol. 3, no. 6, pp.13495-13506, 2014.

[12] Krawinkler H, Seneviratna G D P K, “. Pros and Cons of Pushover Analysis of Seismic Performance Evaluation” Engineering Structures, vol. 20, no. 4-6, pp.452-464, 1998.

[13] Pranata Y A, "Evaluasi Kinerja Gedung Beton Bertulang Tahan Gempa dengan Pushover Analysis (Sesuai ATC-40, FEMA 356, dan FEMA 440)", Jurnal Teknik Sipil, vol. 3, no. 1, pp.41-52, 2006.

[14] Applied Technology Council. ATC 40, Seismic Evaluation an Retrofit of Concrete Buildings (ATC), USA, 1996

[15] Badan Standardisasi Nasional. SNI 1726-2012, Tata Cara Perencanaan Ketahanan Gempa untuk Struktur Bangunan Gedung dan Non Gedung (BSN). INA, 2012

[16] Badan Standardisasi Nasional. SNI 1727-2013, Beban Minimum untuk Perancangan Bangunan Gedung dan Struktur Lain (BSN). INA, 2013 
[17] Departemen Pekerjaan Umum. PPURG, Pedoman Perencanaan Pembebanan untuk Rumah dan Gedung (Yayasan Badan Penerbit PU). INA, 1987

[18] Badan Standardisasi Nasional. SNI 1726-2002, Standar Perencanaan Ketahanan Gempa untuk Struktur Bangunan Gedung (BSN). INA, 2012

[19] Oh S H, Jeon J, “. A Study on Optimum Distribution of Story Shear Force Coefficient for Seismic Design of Multistory Structure" International Journal of High-Rise Buildings, vol. 3, no. 2, pp.121-145, 1994.

[20] Budiono B, Dewi N T H, Kristalya M, Manik S L C, Ong E H K, Contoh Desain Bangunan Tahan Gempa dengan Sistem Rangka Pemikul Momen Khusus dan Sistem Dinding Struktur Khusus di Jakarta (Penerbit ITB), INA, 2017 